\title{
Baker Hughes: Greasing the Wheels in Kazakhstan (FCPA Violations and Implementation of a Corporate Ethics and Anti- Corruption Compliance Program
}

\author{
Mark Holtzblatt \\ Cleveland State University, m.holtzblatt@csuohio.edu \\ Norbert Tschakert
}

Follow this and additional works at: https://engagedscholarship.csuohio.edu/bus_facpub

Part of the Business Law, Public Responsibility, and Ethics Commons, and the Finance and Financial Management Commons

How does access to this work benefit you? Let us know!

\section{Publisher's Statement}

NOTICE: this is the author's version of a work that was accepted for publication in Journal of Accounting Education. Changes resulting from the publishing process, such as peer review, editing, corrections, structural formatting, and other quality control mechanisms may not be reflected in this document. Changes may have been made to this work since it was submitted for publication. A definitive version was subsequently published in Journal of Accounting Education, 32 (2014); 10.1016/j.jaccedu.2014.01.005

\section{Original Published Citation}

Holtzblatt, M., Tschakert, N. (2014). Baker Hughes: Greasing the Wheels in Kazakhstan (FCPA Violations and Implementation of a Corporate Ethics and Anti-Corruption Compliance Program. Journal of Accounting Education, 32, pp. 36-60.

This Article is brought to you for free and open access by the Monte Ahuja College of Business at EngagedScholarship@CSU. It has been accepted for inclusion in Business Faculty Publications by an authorized administrator of EngagedScholarship@CSU. For more information, please contact library.es@csuohio.edu. 


\title{
Baker Hughes: Greasing the wheels in Kazakhstan (FCPA violations and implementation of a corporate ethics and anti-corruption compliance program)
}

\author{
Mark Holtzblatt ${ }^{\mathrm{a}, \boldsymbol{*}^{*}}$, Norbert Tschakert ${ }^{\mathrm{b}, 1}$ \\ ${ }^{2}$ Monte Ahuja College of Business, Cleveland State University, 1860 E. 18th Street, Monte Ahuja Hall, Cleveland, \\ OH 44115-2214, United States \\ ${ }^{b}$ Bertolon School of Business, Salem State University, 352 Lafayette Street, Salem, MA 01970, United States
}

\footnotetext{
* Corresponding author. Tel.: +1 216875 9711; fax: +1 2166879212.

E-mail addresses: m.holtzblatt@csuohio.edu (M. Holtzblatt), ntschakert@salemstate.edu (N. Tschakert).

1 Tel.: +1978542 6627; fax: +19785426027.
} 


\section{Introduction}

Put yourself into the position of a new member of the Baker Hughes audit committee. The audit committee is crucial to the governance of Baker Hughes through its monitoring of the financial accounting, reporting, and internal control processes of the company. Your new responsibilities require you to assess numerous risks and to evaluate control activities. The audit committee's responsibilities also include: reinforcing and monitoring external audit quality; monitoring the effect of the business and regulatory environment on Baker Hughes' compliance program; and ensuring that internal audit is properly focused on key areas of risk (KPMG Audit Committee Institute, 2012). One important area of risk is the risk of corruption, including that related to the Foreign Corrupt Practices Act (FCPA):

Audit Committees are often directly involved in assessing whether management has developed and is maintaining an effective compliance program to address corruption risk ... While recent trends suggest that FCPA enforcement has increased, guidance from regulators has provided clarity regarding proactive steps companies can take to mitigate their corruption exposure. An effectively designed, implemented, and managed compliance program tailored to a company's specific risk areas is paramount. The audit committee plays an integral role in confirming these objectives are met (Deloitte, 2013).

Baker Hughes is a Texas-based public company that helps the oil and gas industries develop their reservoirs. Baker Hughes has 58,000-plus employees in more than 80 countries (Baker Hughes Inc., 2013). In 2007, Baker Hughes rose to the top of an exclusive list, but obviously not one that it aspired to. On April 26, 2007, the company announced that:

... it was settling a federal probe alleging that it violated the Foreign Corrupt Practices Act (FCPA), and that it would pay fines and penalties in excess of $\$ 44$ million, which at the time was the largest combined punishment under the FCPA (Baker Hughes, 2007a). The company's punishment included an $\$ 11$ million criminal penalty, a $\$ 10$ million civil penalty, the requirement to disgorge almost $\$ 20$ million in ill-gotten profits and prejudgment interest of $\$ 3.1$ million. Moreover, the company reported that the five-year internal probe cost over $\$ 50$ million, involved 330 lawyers, 31 forensic accountants, the review of hundreds of thousands of pages of hard-copy documents and 1.69 tetra-bytes of electronic data (the equivalent of 90 million pages) from computers in 20 cities on four continents (Baker Hughes Inc., 2007b).

You look out upon your desk at the many documents you have collected in your desire to determine what had led to such a corporate debacle. The documents include the original court complaint of the SEC vs. Baker Hughes and Roy Fearnley, press releases, government publications, 10-K annual reports, and other materials. You want to ascertain that Baker Hughes was implementing the necessary actions to prevent such problems from recurring.

At this stage of your review of relevant documents, you had narrowed your investigation to the questionable actions of Roy Fearnley, a previously hired employee for operations in Kazakhstan. The Republic of Kazakhstan is located in Central Asia and Eastern Europe and it is the ninth largest country in the world (Kazakhstan.com, 2013). It holds 4 billion tons of proven recoverable oil reserves and is estimated to be in the top-10 oil-producing nations in the world by 2015 (GlobalEdge, Michigan State University, 2013). The website of Transparency International lists Kazakhstan as a highly corrupt country (Transparency International, 2014). You decide to first investigate the recent trend in the number of newly initiated FCPA enforcement actions and the size of penalties assessed.

\section{FCPA enforcement actions and fines are increasing}

The FCPA prohibits companies, employees, and agents from giving anything of value to foreign government officials in order to obtain or retain business. The law also requires public companies to maintain robust internal controls and accurate record-keeping on the expenditure of corporate 
funds. The U.S. Congress enacted the FCPA in 1977 and revised it in 1988. The FCPA was initially created in response to corporate scandals that were discovered in the mid-1970s. At that time, more than 400 U.S. companies admitted to paying over $\$ 300$ million in bribes to foreign government officials (U.S. Department of State, 2001).

For the first 30 years of the FCPA, enforcement actions were relatively rare, with only a few cases a year. Recently, the Department of Justice (DOJ), the Federal Bureau of Investigation (FBI), the Securities and Exchange Commission (SEC), and foreign regulators have increased their enforcement activities. This is in part due to the PATRIOT Act, the Sarbanes-Oxley Act of 2002, and a series of international anti-corruption conventions. International agreements targeting foreign corruption include the $O E C D$ Convention on Combating Bribery of Foreign Public Officials in International Business Transactions created in 1997, and the UK Bribery Act of 2010. Exhibit 1 displays the increase, starting in 2007, of FCPA enforcement cases by the SEC and the DOJ.

In addition to the increased frequency of FCPA enforcement actions, there are larger fines awaiting violators. Scott Friestad, the SEC's Deputy Director for the Enforcement Division, predicted at an SEC presentation on November 24,2008, "The dollar amounts in the cases that will be coming within the next short while will dwarf the disgorgement and penalty amounts that have been obtained in prior cases."

As can be seen in Exhibit 2, Mr. Friestad's prediction has come true.

\section{Baker Hughes crosses the bribery line}

\subsection{Media reports regarding Baker Hughes FCPA transgressions}

During your review as a Baker Hughes audit committee member, you were able to compile the following information and history regarding the numerous Baker Hughes FCPA transgressions in Kazakhstan. The media reports in April 2007 announcing the Baker Hughes FCPA transgressions were hardhitting, as seen in the following excerpts from a New York Times article and the Securities and Exchange Commission press release (see Exhibit 3 ).

\subsection{The Karachaganak oil field project and Karachaganak Integrated Organization (KIO)}

In November 1997, the Government of Kazakhstan and Kazakhoil, Kazakhstan's national oil company signed a 40-year Production Sharing Agreement with the members of the Karachaganak Integrated Organization (KIO). KIO members included: (1) Eni-AGIP S.p.A. (Italy); (2) British Gas

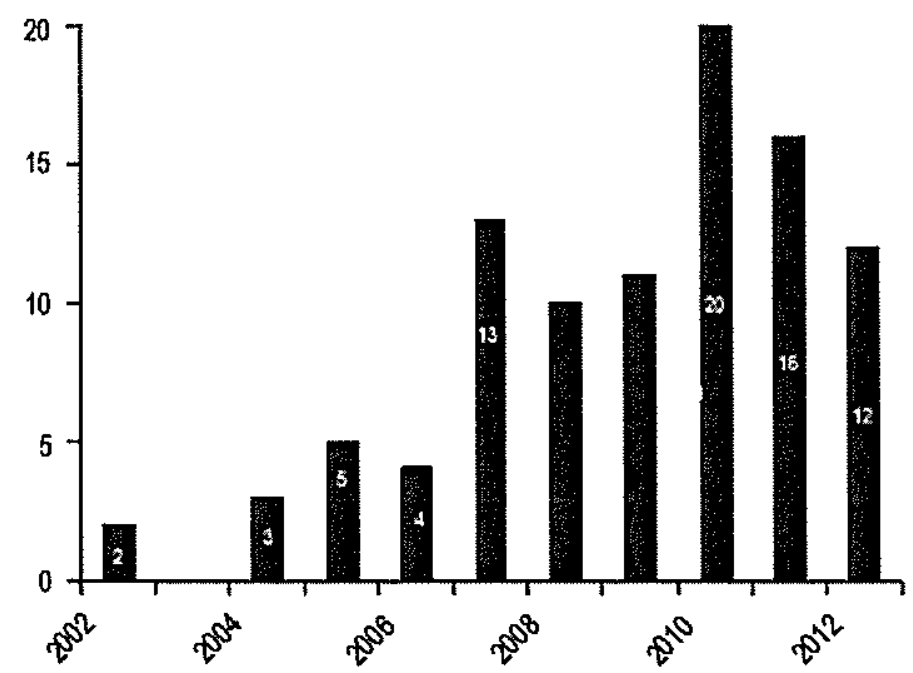

Exhibit 1. Increasing FCPA enforcement cases by the SEC and DOJ. Source: Urofsky and Newcomb (2013). 


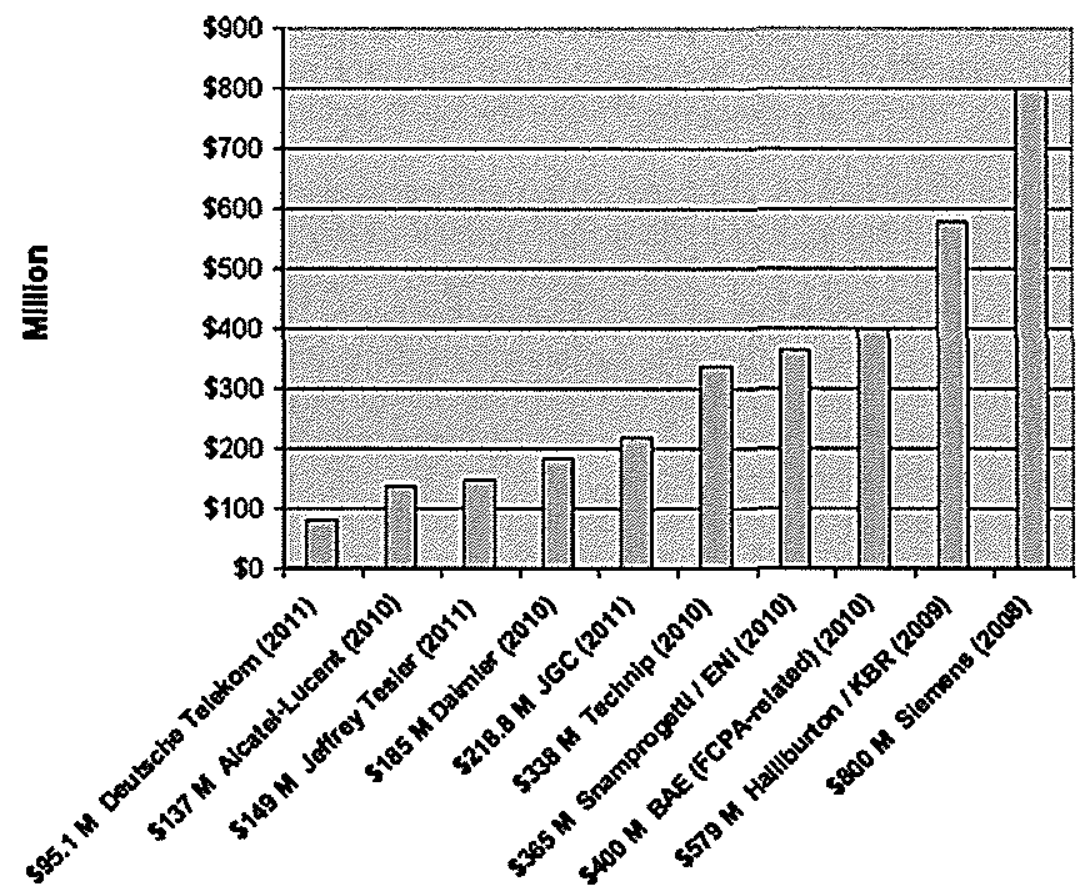

Exhibit 2. Rising penalties from FCPA violations by the SEC and DOJ. Source: Miller Chevalier (2011).

Exploration and Production Ltd. (United Kingdom); (3) ChevronTexaco (United States); and (4) Lukoil Oil Co. (Russia). The purpose of the KIO is the development of the Karachaganak oil project located in Aksai, Kazakhstan (Karachaganak Petroleum Operating, 2002). Exhibit 4 displays the location of the oil field project.

To help develop the oil field project, the KIO members decided to contract with an oil drilling services company. Services sought by KIO included project management, oil drilling, logistics, and engineering.

Kazakhoil was in charge of managing all oil and gas operations in Kazakhstan. Thus, KIO sought Kazakhoil's approval during various phases of the contract-bidding process. Baker Hughes believed that the probability of winning the KIO oil services contract depended, to a great extent, on Kazakhoil's approval.

Revenue from the KIO contract was anticipated to be in the range of $\$ 200$ million. A high-ranking Baker Hughes' executive stated in November of 1999 that winning the Karachaganak oil-field contract was "crucial for the future health of Baker Hughes in Kazakhstan" (SEC v. BH. 2007).

\subsection{Baker Hughes and the KIO tender process}

During your review of the SEC vs. Baker Hughes court complaint, you have constructed the following timeline of relevant events that related to the KIO contract bidding process:

October 1998:

- Baker Hughes learns about the KIO oil drilling services contract and prepares its bid.

December 1998:

- Roy Fearnley, Baker Hughes' Business Development Manager for Kazakhstan, was appointed "Team Leader" to manage Baker Hughes' contract bid.

- Fearnley made contact with a high-level executive of Kazakhoil, who possessed significant decision-making authority on the KIO contract. 


\title{
Ehe New Hork Eimes
}

\author{
Baker Hughes Admits to Overseas Bribery \\ By Floyd Norris, Published April 27, 2007 \\ Baker Hughes, a large oil services company, pleaded guilty yesterday to violating the foreign \\ comupt practices act by bribing foreign officials, an action that continued even after the \\ company promised in 2001 to stop making such payments. \\ The criminal charges covered payments to win oil field contracts in Kazakhstan, but the \\ company also settled civil charges filed by the Securities and Exchange Commission accusing it \\ of making illegal payments in five other countries - Angola, Indonesia, Nigeria, Russia and \\ Uzbekistan.
}

Source: Norris (2007)

\section{U.S. SECURITIES AND EXCHANGE COMMISSION}

\section{Litigation Release No. 20094/April 26, 2007}

\section{SEC Charges Baker Hughes with Foreign Bribery and with Violating a \\ 2001 Commission Cease-and-Desist Order}

\section{Baker Hughes Subsidiary Pleads Guilty to Three Felony Charges in a Criminal Action Filed by the Department of Justice; Criminal Fines, Civil Penalties and Disgorgement of Illicit Profits Total More Than $\$ 44$ Million}

Source: U.S. SEC (2007a)

Exhibit 3. Media reports announcing Baker Hughes FCPA transgressions. (See above-mentioned references for further information).

Late 1999:

- Baker Hughes is notified that its pre-qualification was successful, and it received the documents needed to prepare its bid. Bidding preparation then commenced.

February 2000:

- Baker Hughes submitted its contract bid to the KIO for the Karachaganak oil services project. Baker Hughes' bid did not contain a provision for hiring an agent nor was such a hiring foreseen or considered necessary to win the bid.

September 12, 2000:

- Fearnley informed his supervisor at the Baker Hughes headquarters in Houston, Texas, the VP of Marketing, that he had heard unofficially that Baker Hughes was the winner of the Karachaganak oil services contract bid and that confirmation would be forthcoming (within a week). 


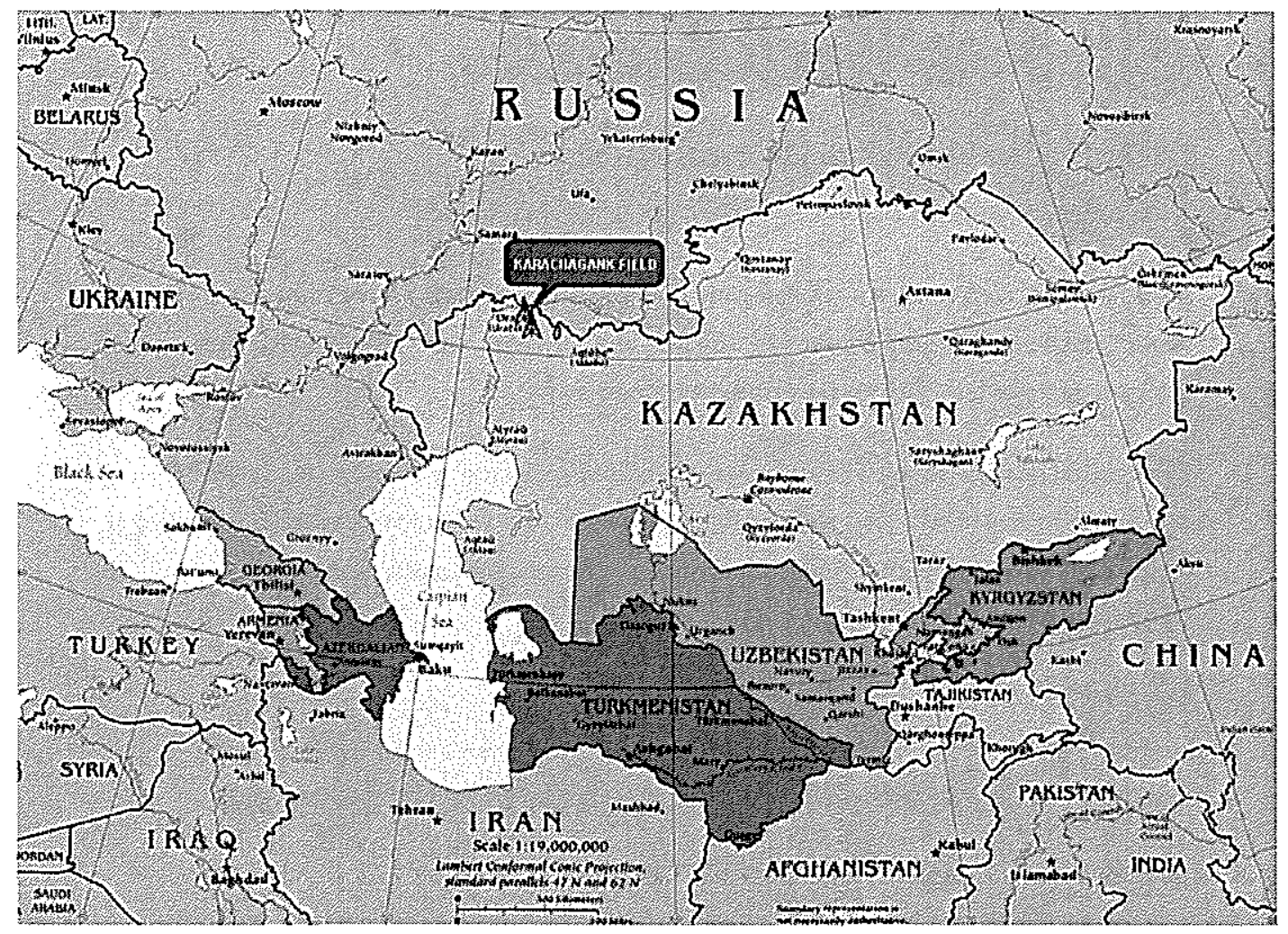

Exhibit 4. The Karachaganak Oil Field Project location. Source: Crude Accountabiliry (2013).

\subsection{Baker Hughes approached by "Kazakhoil ... through an agent"}

\subsubsection{The request for a commission}

As you continue your review of the SEC court complaint, you discover a series of alarming quotes from September 14, 2000:

- "Kazakhoil requested that Baker Hughes hire an agent in connection with the Karachaganak tender (bid)."

- "I have heard rumors that the Kazakhs are looking for an agency agreement. I hope not at this late stage."

- "As you know ... Kazakhoil approached me through an agent in London stating that to get the Kazakhoil approval a commission is required."

- "If one of our competitors comes in with a pot of gold, it is not going to be our contract."

After reading these quotes, you write down the notes shown in (Exhibit 5) regarding events that had occurred after September 14, 2000.

This last-minute request for commissions to an agent was disconcerting because the FCPA expressly prohibits corrupt payments made through third parties or intermediaries. Specifically, it covers payments made to any person, while knowing that all or a portion of such money or thing of value will be offered, given, or promised, directly or indirectly, to a foreign official (DOJ \& SEC, 2012). Many companies doing business in a foreign country retain a local individual or company to help them conduct business. Although these foreign agents may provide entirely legitimate advice regarding local customs and procedures and may help facilitate business transactions, companies should be aware of the risks involved in engaging third-party agents or intermediaries. The fact that a bribe is paid by a third party does not eliminate the potential for criminal or civil FCPA liability (DOJ \& SEC, 2012). 


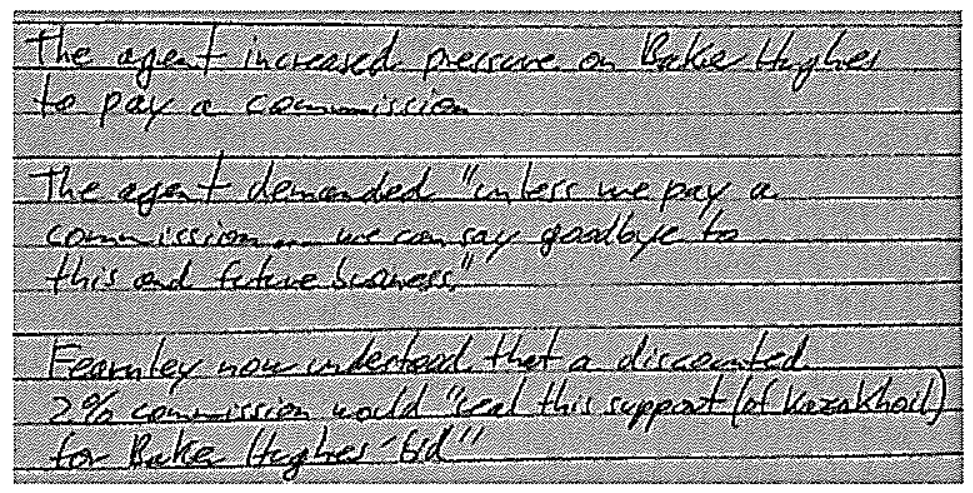

Exhibit 5. Notes taken from court complaint.

Common warning signs or red flags associated with third parties include:

- Excessive commissions to third-party agents or consultants.

- Third-party "consulting agreements" that include only vaguely described services.

- The third party is related to or closely associated with the foreign official.

- The third party became part of the transaction at the express request or insistence of the foreign official.

- The third party is merely a shell company incorporated in an offshore jurisdiction.

- The third party requests payment to offshore bank accounts (DOJ \& SEC, 2012).

\subsubsection{Baker Hughes hires the agent}

Fearnley began to survey the division vice-presidents for their support of the commission. By the following morning (Monday, September 25, 2000), approvals had been obtained from senior officials of the relevant divisions of Baker Hughes.

Fearnley now attempted to finalize the agency contract with the agent, a company located in the Isle of Man led by an individual citizen and resident of the UK. The agent was later identified in 2010, by leaked U.S. diplomatic dispatches (released by Wikileaks), as being Robert Kissin, a UK banker (Leigh, 2010). On September 24 and 25, 2000, Fearnley confirmed with the agent Baker Hughes' agreement to pay the $2 \%$ commission for the Karachaganak project based on the revenues generated from the project and a separate agreement that would appoint the agent as Baker Hughes' agent for all future services in Kazakhstan at a commission of $3 \%$ of revenues invoiced by Baker Hughes on all of its future Kazakhstan projects (SEC v. BH, 2007).

Fearnley's e-mail to the agent referred to the connection between the commission payment and the approval of Baker Hughes' bid: "you will note the consideration has been greatly increased and trust this will receive the recognition it deserves in the necessary corners of Kazakhstan in confirming their support to Baker Hughes" (SEC v. BH, 2007). On September 26, 2000, on the same day that Kazakhoil was expected to support, or not support the Baker Hughes' bid, Fearnley finalized the commission agreement with the agent in the Isle of Man.

By September 29, 2000, Baker Hughes had retained the agent. The agreement provided for a $2 \%$ commission on revenues generated from the Karachaganak project, and it was dependent on Baker Hughes "being confirmed the winner of the tender and awarded the 3-year contract (SEC v. BH, 2007)." The agreement contained no FCPA language at all. Exhibit 6 shows a graphical representation of the entities and transactions involved in the Baker Hughes FCPA violations in Kazakhstan.

\subsection{Baker Hughes' internal controls fail to stop the hiring of the agent}

On or about October 4,2000, the VP of Marketing informed a Baker Hughes' senior attorney that the company was going to hire an agent linked to the Karachaganak oil field project and that the Baker 


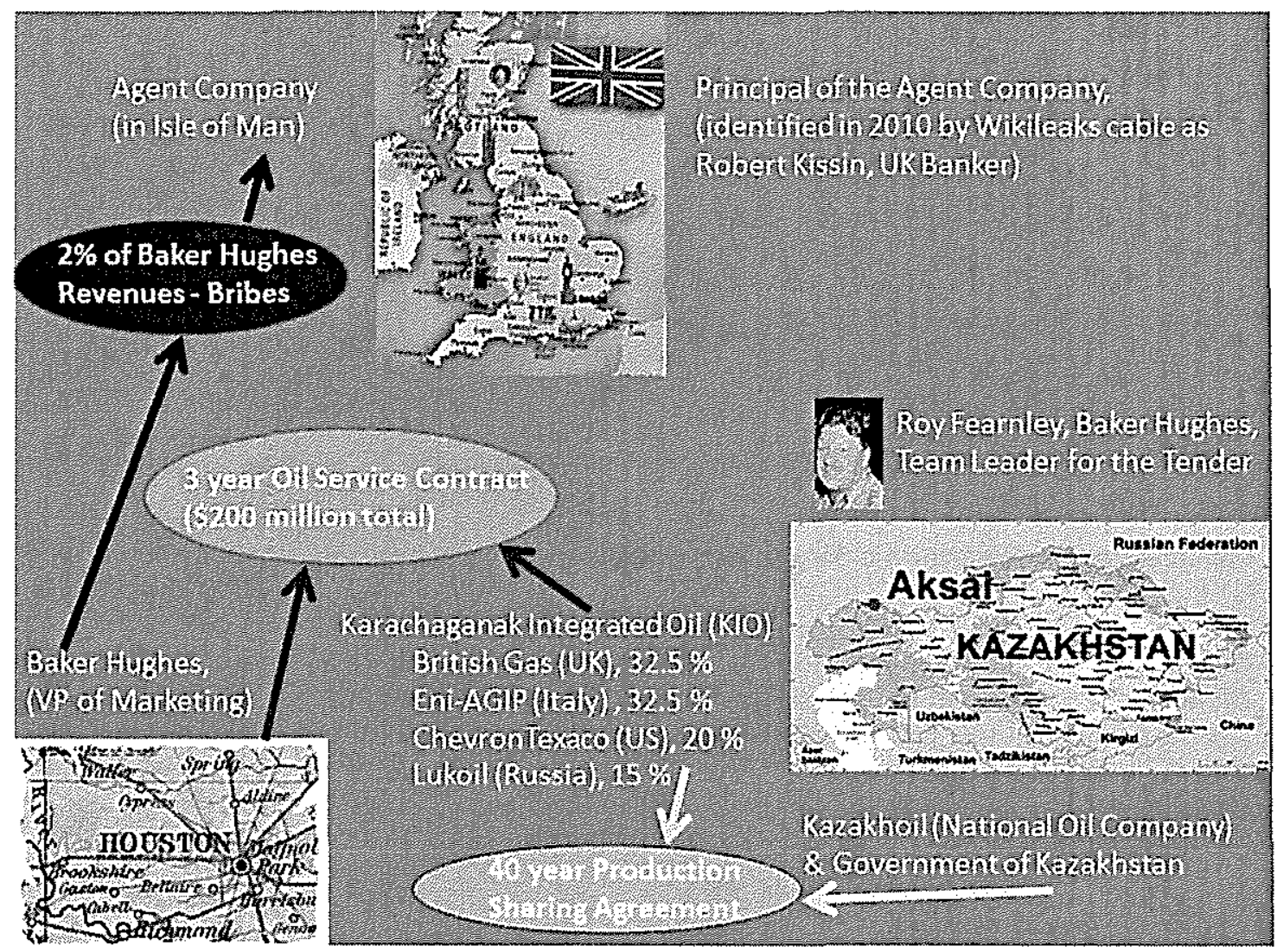

Exhibit 6. The entities and transactions involved in the Baker Hughes FCPA case.

Hughes legal division should communicate with Fearnley to obtain further details. The senior attorney sent Fearnley a copy of Baker Hughes' updated standard FCPA documentation (updated January 2000) including standardized documents for agent contracts, an agent's questionnaire, a questionnaire on the agent's references and a certification for the agent to execute. The senior attorney questioned whether the updated procedures had been followed. Fearnley stated that he would try to substitute an agreement using the updated, approved, document, and said: "There are still some issues such as a Dun and Bradstreet search to be done but I will follow all the issues as notified and advise you if we have any issues not in compliance with the thorough documents and procedures received" (SEC v. BH, 2007).

Fearnley did not follow any of the FCPA procedures communicated to him by Baker Hughes' legal division and the division did not follow up with Fearnley. Nobody verified that the updated FCPA procedures had been followed and nobody performed any significant due diligence on the agent until 2003.

\subsection{Baker Hughes is awarded the Karachaganak tender}

On October 12,2000 , less than three weeks after hiring the agent to represent Baker Hughes' in Kazakhstan and over a year subsequent to Baker Hughes trying to win the contract, Fearnley learned that Baker Hughes would be receiving communication from the KIO selecting Baker Hughes as the winner of the Karachaganak contract. Soon thereafter, Baker Hughes was officially awarded the Karachaganak contract. During May 2001, Baker Hughes started the first of a series of payments to the agent according to the agreement, equal to $2 \%$ of revenues generated by the Karachaganak oil field project (SEC v. BH, 2007). 


\subsubsection{Payments to the agent}

During the years 2001-2003, Baker Hughes made 27 commission payments totaling about $\$ 4.1$ million to the agent in the Isle of Man, related to the Karachaganak oil field project contract. The payments were calculated as being a $2 \%$ commission on net revenues earned by Baker Hughes on the project. Despite the fact that the agent was a company registered in the Isle of Man, allegedly providing services for Baker Hughes in Kazakhstan, every commission paid was disbursed from a Baker Hughes' U.S. account to a bank account located in London under the name of the agent (SEC v. $\mathrm{BH}, 2007)$.

The commissions paid were subsequently recorded in the accounting system of Baker Hughes and inaccurately classified as "commissions," "fees," or "legal services." There were no legal or other services provided by the agent for Baker Hughes. Baker Hughes earned about $\$ 220$ million in total revenues on the Karachaganak oil field project (SEC v. BH, 2007).

\subsection{The judgment}

Without admitting or denying the SEC's allegations, Baker Hughes consented to the entry of a final judgment permanently disallowing any future violations of the FCPA and ordering it to pay a civil penalty and disgorgement with prejudgment interest ${ }^{2}$ (SEC, 2007b).

The Commission acknowledged Baker Hughes' cooperation in the investigation. In a related criminal proceeding, the United States Department of Justice filed criminal FCPA charges against Baker Hughes and its wholly owned subsidiary Baker Hughes Services International, Inc. Baker Hughes Services International, Inc., which has an office in Atyrau, Kazakhstan, entered a guilty plea and "agreed to plead guilty to one count of violating the anti-bribery provisions of the FCPA, one count of aiding and abetting the falsification of the books and records of Baker Hughes, and one count of conspiracy to violate the FCPA, as well as to pay a criminal fine of $\$ 11$ million. The Department of Justice also entered into an agreement with Baker Hughes to defer prosecution for two years on charges of violating the anti-bribery and books and records provisions of the FCPA. Under the agreement, the company consented to retain for a period of three years an independent monitor to review and assess the company's compliance program and monitor its implementation of and compliance with new internal policies and procedures" (SEC. 2007b).

\section{Lack of internal controls}

During your audit committee review of documents, you discover that "according to Baker Hughes' settlement agreements with the DOJ and the SEC, the company maintained insufficient internal controls to avoid FCPA violations. The FCPA contains an obligation for public companies such as Baker Hughes to maintain robust internal controls. The settlement documents identify several of the firm's alleged shortcomings, including the following:

- Baker Hughes had roughly 650 business intermediaries (reduced to fewer than 80 as a result of the internal investigation and settlements) around the world, including local sales agents hired to help identify potential business transactions and to promote the company to prospective customers. According to the SEC and DOJ, Baker Hughes did not conduct adequate due diligence on its intermediaries to ensure that they had a reputation for ethical business conduct, were qualified to perform the services for which they had been retained, or were not inappropriately close to influential government officials. The company repeatedly retained the services of local agents without determining who owned or controlled the agents. Sales commissions were unreasonably large, and in some instances, negotiated by a foreign official on behalf of an agent.

\footnotetext{
${ }^{2}$ Disgorgement forces a violator to give up the amount by which he or she was unjustly enriched (Anterican Bar Association, 2007). Prejudgment interest is interest that is added to a judgment from the time of the violation to the date of the judgment (Hasen, 2012).
} 
- The company had no written agreements with many of its intermediaries. It paid intermediaries outside of their home jurisdictions. In short, according to the SEC, Baker Hughes retained and made payments to intermediaries under circumstances in which the company failed to adequately ensure itself that such payments were not being passed on to foreign officials.

Baker Hughes appears to have lacked sufficient accounting controls to ensure that payments made using corporate funds were appropriate and consistent with the law. Agents were sometimes paid in cash. One agent received payments in five different bank accounts outside of his home jurisdiction. Payments were made for an option to lease land from a company in Kazakhstan after a Baker Hughes employee determined that the company was only a front for the real owners who are influential. Agents were reimbursed for expenses incurred in providing personal travel to foreign officials and their families. Commission payments to a local agent were described in the company's books and records as "legal fees" (SEC v. BH, 2007).

\section{Baker Hughes' renewed commitment to strong ethics and legal compliance}

After completing your audit committee review of the history of Baker Hughes' questionable payments in Kazakhstan and violations of internal control, you are encouraged by the subsequent actions of the company's management. Following the settlements with the DOJ and the SEC, Chad Deaton, former chairman and chief executive officer of Baker Hughes, said:

Since the commencement of these investigations in 2002, we have cooperated fully with the SEC and DOJ. We conducted our own rigorous, independent investigation and we have openly shared our findings with these agencies. The acts which resulted in these enforcement actions are contrary to our core values, our policies and our expectations for ethical behavior. The company has terminated employees and commercial agents that it believes were directly involved. In addition, we have further strengthened the compliance culture within the company by making extensive improvements and enhancements to our compliance program (Baker Hughes, Inc., 2007b).

Our employees and management have demonstrated their strong commitment to ethical business conduct and strict compliance with the law over the past several years, and the progress of our programs to benchmark and to continue to improve our compliance are on track. There is no doubt that our renewed commitment to strong ethics and legal compliance complements our Best-in-Class technology and our reputation for reliability and project execution (Baker Hughes, Inc., 2007b).

Over the ensuing years Baker Hughes embarked on a process to continuously improve its compliance program to a best-in-class standard and to minimize the role that commercial agents play in their business model. Mr. Deaton said:

The significant steps we have taken over the past few years to strengthen our global compliance program will play an important role in reinforcing this company's strong historical reputation for integrity and ethical behavior. Baker Hughes is committed to continued improvement in our compliance program with particular emphasis on the FCPA. We are ready to work closely with the compliance monitor to demonstrate the effectiveness of our current compliance program and to build upon the improvements we have already made (Baker Hughes, Inc., 2007b).

You also discover that Baker Hughes publishes and periodically updates several policy booklets as part of their ethics and compliance programs. The two booklets are entitled: (1) "Baker Hughes Business Code of Conduct" (Baker Hughes Inc., 2010), and (2) "Baker Hughes Guide to Complying with the FCPA" (Baker Hughes Inc., 2011).

\section{Case questions}

1. In the four-minute video History of the FCPA (PBS, 2009) (http://youtu.be/g1nOkat_i4s), former SEC Assistant Director Richard Grimes states that there are three parts of the FCPA that relate to both the accounting and bribery provisions. The U.S. DOJ also provides "An Overview" 
(DOJ, 2013) of the FCPA provisions (www.justice.gov/criminal/fraud/fcpa). Requirements: (a) Describe briefly what the three FCPA parts referenced in the video are; and (b) describe briefly how Baker Hughes violated these accounting and bribery provisions in its Kazakhstan operations.

2. In responding to the 2007 penalties, Baker Hughes has created an FCPA Compliance Guide (Baker Hughes, Inc., 2011) that facilitates employee understanding and compliance with the FCPA (www.bakerhughes.com/company/compliance/foreign-corrupt-practices-act). Refer to Section 2 of the guide on page 14 and describe Baker Hughes' "Financial Integrity" requirements.

3. Access the source document entitled A Resource Guide to the U.S. Foreign Corrupt Practices Act (U.S. DOJ \& SEC, 2012) provided on the SEC website (www.sec.gov/spotlight/fcpa/fcparesource-guide.pdf). What are the criminal and civil penalties for both individuals and corporations in violation of the anti-bribery and accounting provisions of the FCPA?

4. The case mentions local laws such as Sarbanes-Oxley (SOX) of 2002 (U.S. Congress, 2002) and the UK Bribery Act of 2010 (Legislation.gov.uk, 2010), as well as international anti-bribery agreements that have been created by the OECD in 1997 (OECD, 1997). As a Baker Hughes audit committee member, what would you want Baker Hughes employees to be aware of as regards SOX, the UK Bribery Act, and the OECD Convention?

5. What are the components of an effective Corporate Ethics and Anti-Corruption Compliance Program that audit committee members should consider implementing when facing risks similar to the FCPA risks that Baker Hughes faced? Refer to the April 26, 2007 Baker Hughes press release (Norris, 2007), which is available on the Baker Hughes website under the tab titled "Press Room" (www.bakerhughes.com/news-and-media/media-center/press-releases/4-262007-4-30-00-pm-baker-hughes-settles-previously-disclosed-fopa-investigations).

6. Various "red flags" can provide clues and tip a company off as to where FCPA risks may be lurking. During your audit committee review, you accessed the PowerPoint presentation, slides 2125, by Jay Martin, Baker Hughes' Vice President and Chief Compliance Officer, that was given on June 5, 2008 (Martin, 2008) and reviewed the "red flags" listed there (www.docstoc.com/docs/ 2363177/Baker-Hughes-Incorporated-FCPA-Due-Diligence-Review-of-Non-U.S). In your opinion, which of the warning signs were likely present during the Kazakhstan FCPA violations? Describe the specific Baker Hughes case fact or action that relates to each red flag.

7. The COSO report "Internal Control-Integrated Framework" (COSO, 2013) is the most commonly used and understood framework for evaluating internal controls over financial reporting. Since anti-bribery compliance programs are part of internal control, understanding the coso framework is useful. Access the COSO Framework Executive Summary (www.coso.org/documents/ 990025P_Executive_Summary_final_may20_e.pdf). List and discuss each of the five components for effective internal control. Do you think that adherence to the COSO framework would have had the capacity to prevent Baker Hughes' FCPA violations? Why or why not?

8. As a Baker Hughes audit committee member, you want to determine that the company performed the proper accounting and disclosure of the Kazakhstan violations and settlement. Access the Baker Hughes 10-Ks for the years 2005, 2006, 2007, and 2008 (Baker Hughes, $2005,2006,2007 \mathrm{c}, 2008$ ) from the SEC website (www.sec.gov/edgar/searchedgar/companysearch.html) and do the following: (a) For each year, conduct a search (using the Control $+\mathrm{F}$ keys) for the word "FCPA." How did Baker Hughes account and disclose its Kazakhstan risk exposure during each of the four years? In your opinion, was their accounting treatment correct? (b) Using the most recent 10-Ks available, how did Baker Hughes' revenue develop in the years subsequent to 2007 ? Were Baker Hughes' revenues negatively impacted by the cessation of bribery activities under the FCPA?

9. To what extent do external auditors have a responsibility to detect violations of the FCPA? What specific actions must external auditors take to discover fraud and illegal acts? Refer to AU 317 Illegal Acts by Clients (PCAOB, AU 317) and AU 316 Consideration of Fraud in a Financial Statement Audit (PCAOB, AU 316).

10. In your opinion, what action should (a) an audit committee member, (b) an external auditor, and (c) an employee take if he/she detects a possible violation of the FCPA? 


\section{Teaching notes}

\subsection{Background and learning objectives}

\subsubsection{Background}

The World Bank estimates that more than $\$ 1$ trillion is paid in bribes each year (World Bank, 2004). Transparency International explains: "Corruption destroys entrepreneurship, inhibits free markets and undermines the stability vital to successful economies. It also enables an enormous flow of illicit money outside the real economy - in the form of unpaid taxes, bribes and laundered funds" (Transparency International. 2012). Corruption can only be fought successfully if people refuse to participate in corrupt activities (Biegelman \& Biegelman, 2010). Even though at first sight corruption may seem to benefit individual businesses, businesses overall would benefit greatly if corruption could be reduced (Loughman \& Sibery, 2012).

The Baker Hughes case therefore addresses an important problem typically not dealt with enough in the accounting curriculum. Since 2007, the Department of Justice, FBI, SEC, and foreign regulators have sharply increased their FCPA and anti-bribery enforcement activities. FCPA penalties and costs of internal investigations are a significant cost for both corporations and individuals. Accounting firms are increasing their FCPA compliance and anti-bribery services to businesses. These significant events and trends are occurring in the US and globally, and accounting educators should strongly consider bringing the FCPA and anti-bribery issues into the classroom.

However, the coverage of the FCPA in textbooks and the accounting curriculum has severely lagged these developments. Exhibit TN-1 shows the author's analysis of FCPA coverage within leading accounting and business law textbooks. As can be seen, the coverage of the FCPA is scant in accounting textbooks. FCPA coverage within business law textbooks is also lacking, and does not include in-depth discussion of the FCPA's internal control or accurate books and record-keeping provisions. The experiences with this disconnect between the real-world FCPA developments and available academic materials have led to the creation of this case.

In accordance with the Pathways Commission recommendation to encourage more collaboration between accounting practitioners and academicians, the authors organized a panel at the 2013 AAA Annual Meeting in Anaheim, "The Importance of the FCPA to Accounting Education." One of the FCPA practitioner panelists, Marcus Wong of EY, emphasized that the FCPA is a topic that should be covered in multiple courses within the accounting and business curriculum, not just a single course. This case was written with that goal in mind and the case can be used in numerous courses such as international accounting, auditing, AIS, and forensic accounting.

In 2013, the FCPA case "Nature's Sunshine Products: Anatomy of an FCPA Failure" was published in Issues in Accounting Education (August 2013, Vol. 28, No. 3, pp. 599-610). There are some similarities between the Nature's Sunshine Products case and the Baker Hughes case, but there are also very significant differences as to scope, penalties, topics covered, and supplementary and complementary materials. Exhibit TN-2 shows a comparison of the similarities and differences of the two FCPA cases. The Baker Hughes case involved significantly higher and more diverse penalties and fines in addition to a $\$ 50$ million cost of internal investigation. The Baker Hughes case also covers the topics of external auditor responsibilities and FCPA compliance programs, which are absent in the Nature's Sunshine Products case. The Baker Hughes case is written in second person which immerses the student in a more direct and realistic situation. Finally, the Baker Hughes case provides a dedicated complementary website with numerous original source SEC, DOJ, and company documents, in addition to engaging FCPA related videos. The dedicated website for the Baker Hughes case also contains a set of PowerPoint slides that instructors can use to stimulate and enhance in-class discussion of the topic and case.

At the outset of the case, students are put into the perspective of a newly appointed audit committee member at Baker Hughes, subsequent to the company's 2007 SEC and DOJ settlements. The audit committee member is trying to learn about the FCPA violations the company committed in Kazakhstan in the late 1990s through 2003, and is also trying to evaluate the company's subsequent compliance program activities, which began in 2007 and continue until today, to avoid similar violations from occurring. The case provides students with a real-world scenario of a FCPA bribery case and 
(A) Schedule of FCPA coverage in the leading auditing textbooks

\begin{tabular}{|c|c|c|c|c|c|c|}
\hline Auditing textbook title and authors & $\begin{array}{l}\text { Publleation } \\
\text { date }\end{array}$ & Editton & Publisher & $\begin{array}{l}\text { Total } \\
\text { pages }\end{array}$ & $\begin{array}{l}\text { Pages of FCPA } \\
\text { coverage }\end{array}$ & $\begin{array}{l}\text { FCPA Cases cited } \\
\text { within Textbook }\end{array}$ \\
\hline $\begin{array}{l}\text { 3. Auditing and Assuronce Services } \\
\text { Arens, Elder, and Beasley }\end{array}$ & 2014 & Isth & Pearson & 864 & 1 paragraph (p. 127) & nane \\
\hline $\begin{array}{l}\text { 4. Principles of Auditing \& Other Assuronce Services } \\
\text { Whittington, and Pany }\end{array}$ & 2014 & 19th & McGraw-Hill & 880 & Y poge (p. 245) & none \\
\hline
\end{tabular}

(B) Schedule of FCPA coverage in the leading accounting information systems (AIS) textbooks

\begin{tabular}{|c|c|c|c|c|c|c|}
\hline AIS textbook title and authors & $\begin{array}{l}\text { Publication } \\
\text { date }\end{array}$ & Edition & Publisher & $\begin{array}{l}\text { Total } \\
\text { pages }\end{array}$ & $\begin{array}{l}\text { Pages of FCPA } \\
\text { coverage }\end{array}$ & $\begin{array}{l}\text { FCPA Cases clted } \\
\text { within Textbook }\end{array}$ \\
\hline $\begin{array}{l}\text { 1. Accounting Informotion Systems } \\
\text { Romney, and Steinbart }\end{array}$ & 2012 & 12th & Prentice Hall & 697 & 1 parograph (p. 185) & none \\
\hline $\begin{array}{l}\text { 2. Accounting Information Systems } \\
\text { Hals }\end{array}$ & 2013 & 8th & Cengage & 832 & nane & none \\
\hline $\begin{array}{l}\text { 3. Core Concepts of Accounting information Systems } \\
\text { Simklin, Rose, and Norman }\end{array}$ & 2012 & 12th & $\begin{array}{l}\text { John Wiley \& } \\
\text { Sons }\end{array}$ & 532 & 1 sentence $(p .275)$ & none \\
\hline $\begin{array}{l}\text { 4. Accounting Information Systems } \\
\text { Gelinas, Dull, and Whatler }\end{array}$ & 2012 & 9th & $\begin{array}{l}\text { South- } \\
\text { Western }\end{array}$ & 744 & 1 sentence $(p .232)$ & nane \\
\hline
\end{tabular}

(C) Schedule of FCPA coverage in the leading international accounting textbooks

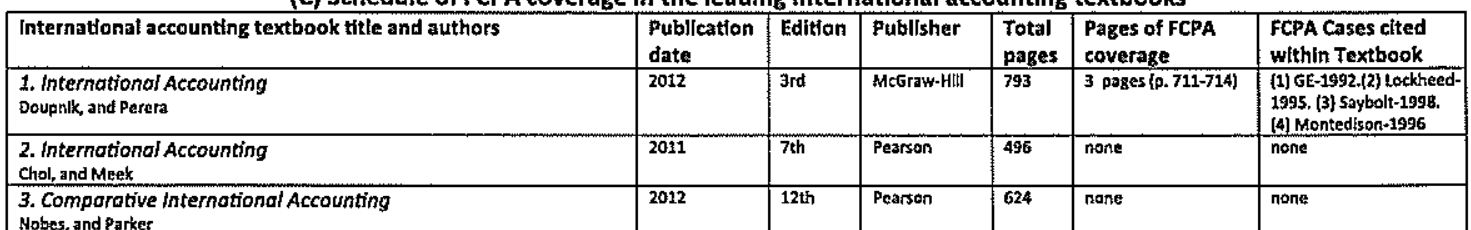

Nobes, and Parkes

(D) Schedule of FCPA coverage in the leading business law textbooks

\begin{tabular}{|c|c|c|c|c|c|c|}
\hline Business Jaw texthook titje and authors & $\begin{array}{l}\text { Publication } \\
\text { date }\end{array}$ & Edition & Publisher & $\begin{array}{l}\text { Total } \\
\text { pages }\end{array}$ & $\begin{array}{l}\text { Pages of FCPA } \\
\text { coverage }\end{array}$ & $\begin{array}{l}\text { FCPA Cases cited } \\
\text { within Texthook }\end{array}$ \\
\hline $\begin{array}{l}\text { 3. Business Law: Text and Coses } \\
\text { Clartson, Miller, and Cross }\end{array}$ & 2012 & 12th & Cengage & 1392 & Kpage (p. 105) & none \\
\hline
\end{tabular}

Exhibit TN-1. FCPA coverage in accounting and business law textbooks.

allows them to explore the difficulties in the decision-making with which companies can be confronted in international business.

\subsection{Learning objectives}

The FCPA is a law that has three major sections: (1) Anti-bribery; (2) Accurate books and recordkeeping; and (3) Functioning internal control. In addition, there are other significant anti-bribery regulations and related auditing standards. The benefit is that students are provided with a holistic perspective of the FCPA and bribery risk issues, rather than a narrow perspective of the problem. Thus, the case has been designed to achieve the following learning objectives (LOs):

(LO 1): Understanding of the importance of the FCPA in global business (i.e., trends, provisions for bribery, accounting, internal control, and penalties for violations)

(LO 2): Knowledge of the ethical considerations of FCPA related activities and actions that can be taken to ensure employee compliance with company policies (FCPA Compliance Guides and Codes of Conduct)

(LO 3): Knowledge of how FCPA violations are reported in the financial statements and disclosed in the footnotes

(LO 4): Knowledge of auditor responsibilities in the occurrence of fraud (related to FCPA violations and COSO internal control standards)

(LO 5): Awareness of how to recognize possible FCPA violations (i.e., "red flags")

(LO 6): Understanding of the options and procedures available to auditors, audit committee members, and employees regarding actions and reporting of possible FCPA violations 


\begin{tabular}{|c|c|c|}
\hline $\begin{array}{l}\text { FCPA Case Company } \\
\text { Journal of publication (year) }\end{array}$ & $\begin{array}{l}\text { Baker Hughes FCPA Case } \\
\text { Journal of Accounting Education, } \\
\text { (2014) }\end{array}$ & $\begin{array}{l}\text { Nature's Sunshine } \\
\text { Products FCPA Case } \\
\text { Issues in Accounting Education, } \\
\text { (2013) }\end{array}$ \\
\hline Industry & Oil Services & Natural Remedies \\
\hline Country involved with bribes & Kazakhstan & Brazil \\
\hline Years that bribes were paid & 2001 to 2003 & 2000 to 2001 \\
\hline Total of bribery payments & $\$ 4.1$ million & "more than $\$ 1$ million" \\
\hline Recipient(s) of bribes & $\begin{array}{l}3^{\text {rd }} \text { party agent in Isle of Man, } \\
\text { funds transferred to Kazakhoil } \\
\text { officials }\end{array}$ & $\begin{array}{l}\text { Customs brokers with some } \\
\text { funds going to customs officials } \\
\text { in Brazil }\end{array}$ \\
\hline Year of Settlement with SEC & 2007 & 2009 \\
\hline Penalties assessed & $\begin{array}{l}\text { \$1 million criminal fine-DOJ } \\
\$ 10 \text { million civil penalty-SEC } \\
\$ 23 \text { million disgorgement } \\
\text { 3-year compliance program and } \\
\text { monitor }\end{array}$ & $\begin{array}{l}\$ 600,000 \text { civil penalty for } \\
\text { company and } \$ 50,000 \text { fine for } \\
\text { two executives }\end{array}$ \\
\hline \multicolumn{3}{|l|}{ Topics Covered in Case } \\
\hline FCPA Anti-bribery provisions & Yes & Yes \\
\hline FCPA Accurate books provisions & Yes & Yes \\
\hline FCPA Internal control provisions & Yes & Yes \\
\hline "Red Flags" to identify FCPA risks & Yes & Yes \\
\hline External auditor responsibilities & Yes & No \\
\hline $\begin{array}{l}\text { Company FCPA Guide and } \\
\text { compliance program }\end{array}$ & Yes & No \\
\hline $\begin{array}{l}\text { Key employees and bribery } \\
\text { recipients identified with their } \\
\text { violations detailed }\end{array}$ & Yes & No \\
\hline Case perspective & $\begin{array}{l}\text { Written in second person with the } \\
\text { student put in the position of a } \\
\text { newly appointed member of the } \\
\text { Baker Hughes audit committee } \\
\text { reviewing the company FCPA } \\
\text { violations and the appropriateness } \\
\text { of the company response }\end{array}$ & Written in third person \\
\hline Written assignments required? & Yes - 10 questions & $\begin{array}{l}\text { No }-2 \text { questions with a } \\
\text { Supplemental question }\end{array}$ \\
\hline $\begin{array}{l}\text { Dedicated case website with SEC and } \\
\text { DOJ FCPA Resource Guide, FCPA } \\
\text { videos, and Company 10-Ks, Company } \\
\text { FCPA Compliance Guide, and } \\
\text { Company Code of Conduct }\end{array}$ & Yes & No \\
\hline $\begin{array}{l}\text { Case PowerPoint Slides provided for } \\
\text { instructor }\end{array}$ & Yes & No \\
\hline
\end{tabular}

Exhibit TN-2. FCPA case similarities and differences - Baker Hughes Case (JAEd) vs. Nature's Sunshine Products Case (IAE).

\subsection{Implementation guidance}

\subsubsection{Incorporating the case into the accounting curriculum and intended audience}

This case can be incorporated in a variety of classes both at the graduate and the undergraduate levels. It can be used in the international accounting, AIS, and forensic accounting courses, especially for those class sessions focusing upon internal control and compliance systems. The Baker Hughes case can also be used in auditing classes as a comprehensive case covering various chapters such as internal control, fraud, and ethics. Finally, for those universities that are offering a separate accounting ethics course within their curriculum, this case would be appropriate. Within the ethics class, sessions that focus upon corporate codes of conduct or specific FCPA guidelines would find this case especially applicable. 
The fraud committed by Baker Hughes is of such magnitude that multiple cases can be derived from it. Instructors can therefore deviate from the provided case to adjust it to their respective class content and need. For example, the topic of internal control could be emphasized even more, requiring more detail on the components of a sound control environment and the "tone at the top." Likewise, the role and responsibility of the internal auditors could be explored and the IMA Statement of Ethical Professional Practice could be used. Business law students could analyze further details of the FCPA as well as additional cases filed by the SEC and the Department of Justice.

This case has been used at two universities over two semesters in international accounting as well as auditing classes. The case was assigned on an individual basis, although it is also feasible as a group project.

\subsubsection{Mapping of the case topics to the LOs and case questions}

Exhibit TN-3 maps the case topics to the learning objectives and case questions. This mapping serves two purposes: (1) to enable instructors to understand the scope of the topics that are encompassed by FCPA issues and that are contained within the Baker Hughes case; and (2) to provide a tool to enable instructors to assign questions to students that are relevant to desired learning objectives and course goals.

\subsubsection{Case website with SEC, DOJ, and company Documents, and FCPA videos}

Students were provided with the dedicated case website www.accountingcase.com, which has links to helpful resources such as the text of the FCPA, SEC and DOJ documents, Baker Hughes' 10$\mathrm{Ks}$, and FCPA and bribery videos. Even though this help was provided, students still had to research the various documents and were able to experience firsthand the difficulties in analyzing complex documents and information. Professors can choose to either refer their students to use or not use the website depending on instructor preferences and time available to research the case. The website includes all the documents, videos and links for student research of the case questions and facilitates directed research. A screenshot of the case website is provided in Exhibit TN-4.

\subsection{Evidence regarding case efficacy}

The case was provided to 131 students at two universities over the course of two semesters, Fall 2012 and Spring 2013. At university one, two sections of auditing students, one in each semester, worked through the case. At university two, four sections of international accounting students, two in each semester, worked through the case. Students were asked to fill out an assessment questionnaire at the due date of the assignment. Responses were made on a five-point likert-type scale (Strongly Agree -1, Agree-2, Neutral-3, Disagree-4, and Strongly Disagree-5). Exhibit TN-5 shows the mean responses for each question.

The statements posed to the students were designed to assess the efficacy of the case in meeting the case learning objectives and the students' overall view of the case. The first six statements in Exhibit $\mathrm{TN}-5$ relate to the case learning objectives and the survey scores ranging from 1.59 to 1.80 indicate that the six learning objectives are supported through the case.

Statements 7-9 related to the students' perceptions of the case's interest and relevancy, and the importance of the FCPA for accountants. Students at both universities found the case interesting and relevant and believe the FCPA is an important topic for accountants. Some of the students had heard about the FCPA before the case was assigned.

The remaining questions showed students responded very favorably to the website provided. They accessed the $10 \mathrm{~K}$ filings on the SEC Edgar Online website and reviewed and described Baker Hughes' FCPA-related disclosures. Students believe that the case is valuable for their career and that it prepares them to better deal with ethical challenges in the workplace.

Furthermore, the assessment shows that responses are quite homogeneous. With the exception of the question "I did not know about the Foreign Corrupt Practices Act before this case was assigned," students rarely opted for "disagree" or "strongly disagree" in their responses.

There were no meaningful deviations in student responses between the fall 2012 and spring 2013 semester or the different sections at the two universities. 


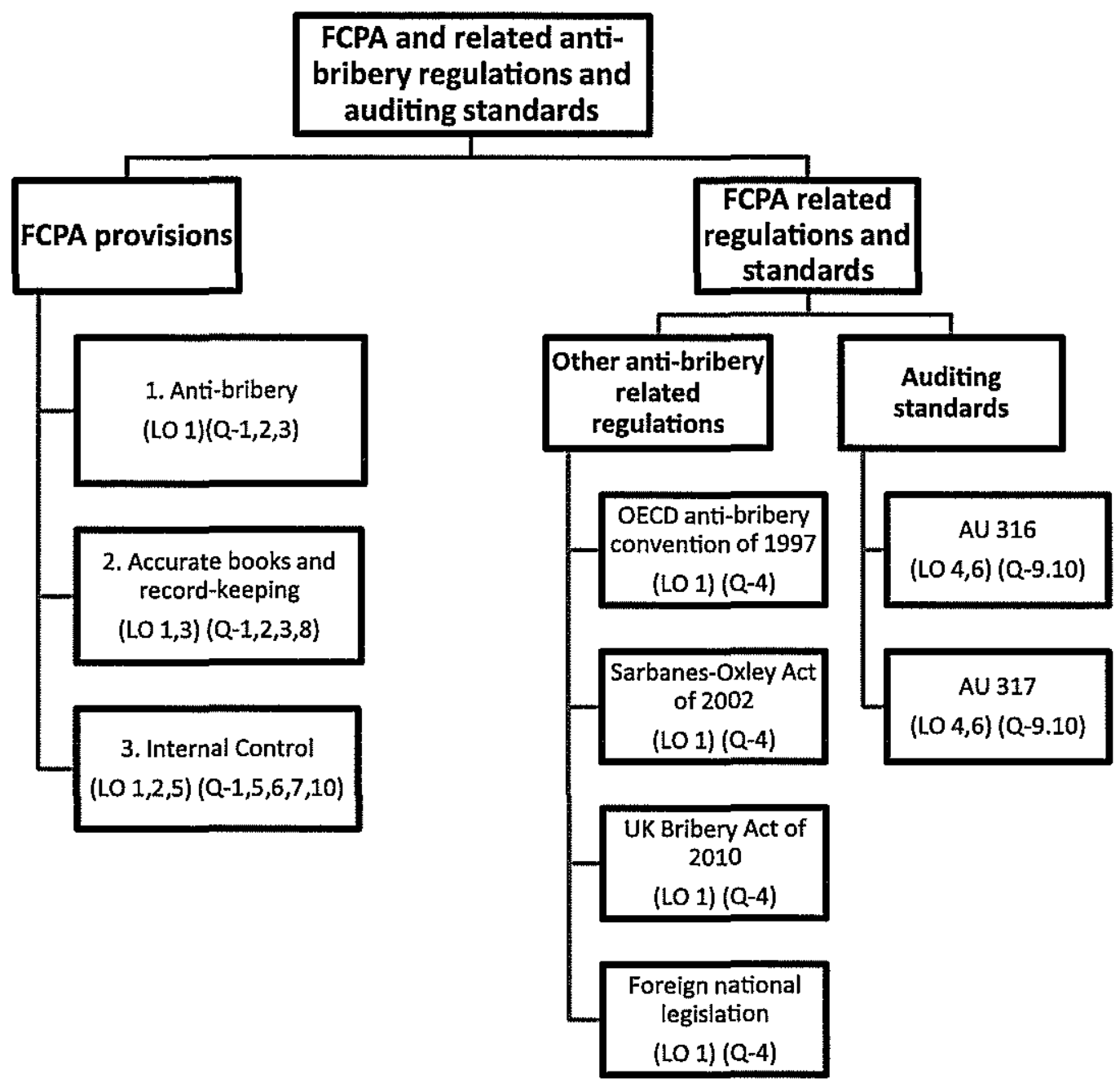

Exhibit TN-3. Baker Hughes case topics mapped to the learning objectives (LO) and case questions (Q).

The questionnaire also included two open-ended questions which most of the students used to provide additional feedback. Student responses to the question "What did you like most about the BH FCPA Case?" included:

- "It was an actual case and interesting to see the effects, especially how Baker Hughes is a 'world class leader' against bribes now."

- "I originally thought to provide commissions in the business world is normal. But now I know it could become an illegal act and should be taken into concern. As an auditor, we should be aware of this issue."

- "I enjoyed learning and researching a real case. Reading how the company accepts and denies fraud and how they attempted to conceal it was very interesting."

- "I like how it was well explained and all the information that was available. I liked how it made me think independently about the subject and be more aware of the rules and regulations."

- "The online resources that went along with the case and the questions. It made it easier to understand everything and answer the questions."

- "I like how the case showed how the tone of upper management pushed the employees to commit violations as well as employees lack of due diligence in regards to FCPA. This case made me aware of FCPA, which I [had] never heard existed." 


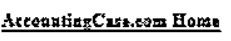

\section{Gezeral FCPA Resources}

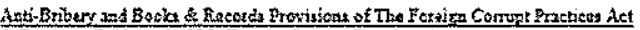

A Regource Guids to the US. Foraran Comupt Practices tot

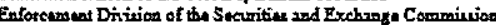

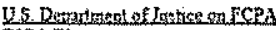

CCPS bion

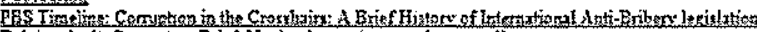

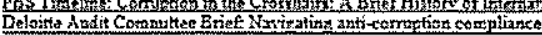

\section{Baker Hughes Case Resources}

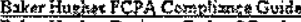

can Code of Costidt

Baker Hughes $10 \mathrm{~K}$ for $2005,2006,2007,2008,2009,2010,2011,2012$

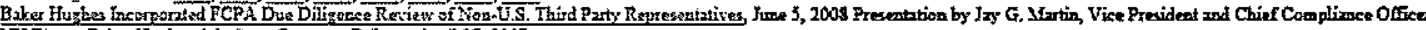

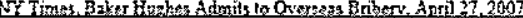

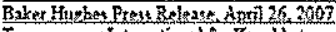

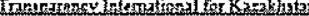

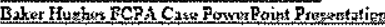

\section{Videos}
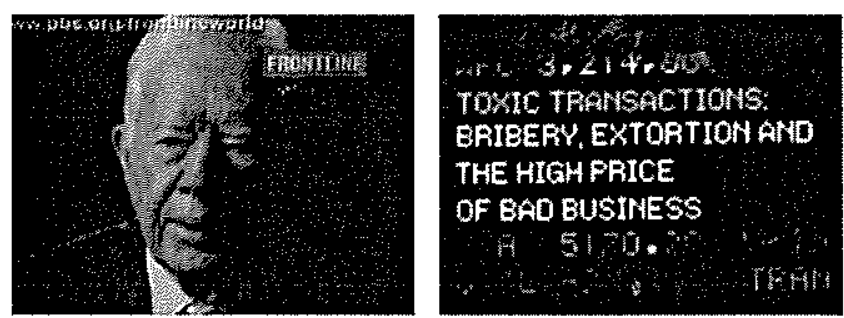

CBS Frontine on the History of the FCPA

Trace International: Bribery, Extortion and the High Price of Bad Business
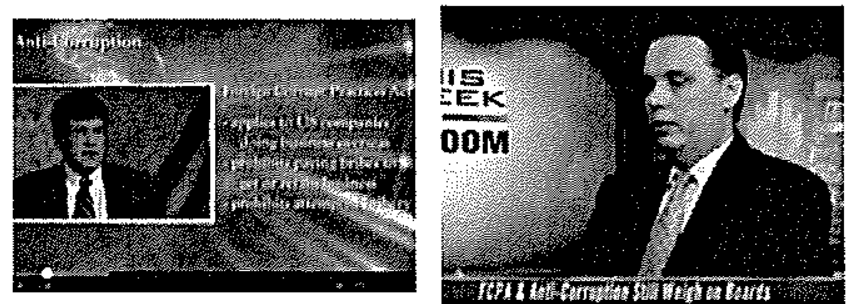

SAI Global Compliance: Complying with the FCPA Oiscussion on This Week in the FCPA:

\section{Anditor Responsibilities}

AV 316 - Consideration of Frud in a Finzaial Stament Audit (PCAOB Webrite) AU 317 - Illexal Acts br Clients (PCAOB W'ebsite)

AS 12 - Identifining and Asseasing Rivks of Material Mristatements (PCAOB Wobsite)

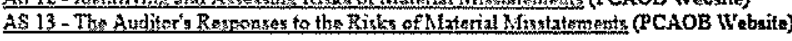

\section{Internal Control}

COSO-Iniarnal Control - Integried Franuxwork

Exhibit TN-4. Dedicated website for the Baker Hughes FCPA case.

- "I feel the research necessary to answer the case questions was similar to what we would expect in our careers."

- "I liked the way the case was written. The moment I started reading I was very interested in finishing. I also liked that it brought out the detective in me."

- "The U.S. is being a good example for other countries. I wish my country would do the same."

- "The application of a real-life situation mixed with accounting principles and reports helped me enjoy the case."

- "Add more cases for other topics because they are interesting and a refreshing change from normal classes." 


\begin{tabular}{|c|c|c|c|c|}
\hline & & University 1 & University 2 & Both Universities \\
\hline & Number of Students in Class & 41 & 90 & 131 \\
\hline & & & & \\
\hline & Learning Objectives Survey Questions (LO 1-6) & & & \\
\hline & & & & \\
\hline 1 & $\begin{array}{l}\text { My understanding of the importance of the Foreign Corrupt } \\
\text { Practices Act was increased by working on this case (LO 1) }\end{array}$ & 1.71 & 1.50 & 1.56 \\
\hline 2 & $\begin{array}{l}\text { The Baker Hughes FCPA case increased my knowledge } \\
\text { knowledge about the importance of Business Ethics (LO 2) }\end{array}$ & 1.73 & 1.72 & 1.73 \\
\hline 3 & $\begin{array}{l}\text { The Baker Hughes FCPA case increased my knowledge } \\
\text { about FCPA related disclosures in financial statements and } \\
\text { footnotes (LO 3) }\end{array}$ & 1.80 & 1.71 & 1.74 \\
\hline 4 & $\begin{array}{l}\text { The Baker Hughes FCPA case increased my knowledge about } \\
\left.\text { auditor responsibilities in the occurrence of fraud ( } \mathrm{LO}_{4}\right)\end{array}$ & 1.73 & 1.74 & 1.74 \\
\hline 5 & $\begin{array}{l}\text { After working through the case, I have a better awareness to } \\
\text { recognize possible FCPA violations (LO 5) }\end{array}$ & 1.68 & 1.56 & 1.60 \\
\hline 6 & $\begin{array}{l}\text { I have a better understanding of the options available to me } \\
\text { should I encounter possible FCPA violations in the workplace } \\
\text { (LO 6) }\end{array}$ & 1.59 & 1.63 & 1.62 \\
\hline & & & & \\
\hline & Other Survey Questions & & & \\
\hline & & & & \\
\hline 7 & I found the Baker Hughes FCPA case interesting & 1.63 & 1.57 & 1.59 \\
\hline 8 & $\begin{array}{l}\text { I found the Baker Hughes FCPA case relevant because it is } \\
\text { based on a real-world company }\end{array}$ & 1.41 & 1.33 & 1.36 \\
\hline 9 & $\begin{array}{l}\text { I believe that the Foreign Corrupt Practices Act is a timely and } \\
\text { important topic for accountants }\end{array}$ & 1.61 & 1.43 & 1.49 \\
\hline 10 & $\begin{array}{l}\text { I did not know about the Foreign Corrupt Practices Act before } \\
\text { this case was assigned }\end{array}$ & 2.20 & 2.54 & 2.44 \\
\hline 11 & $\begin{array}{l}\text { I have accessed the Baker Hughes Financial Statements on the } \\
\text { SEC Edgar Online Website by using the provided links on } \\
\text { www accountingcase.com }\end{array}$ & 1.51 & 1.48 & 1.49 \\
\hline 12 & $\begin{array}{l}\text { I found the information provided on accountingcase.com useful } \\
\text { in helping me to solve this case }\end{array}$ & 1.44 & 1.23 & 1.30 \\
\hline 13 & $\begin{array}{l}\text { I believe that having knowledge about the FCPA will be } \\
\text { valuable for my career }\end{array}$ & 1.51 & 1.49 & 1.50 \\
\hline 14 & $\begin{array}{l}\text { The Baker Hughes case and related questions required me to use } \\
\text { critical thinking skills }\end{array}$ & 1.73 & 1.59 & 1.63 \\
\hline 15 & $\begin{array}{l}\text { Overall, the Baker Hughes FCPA case was a good learning } \\
\text { experience }\end{array}$ & 1.49 & 1.40 & 1.43 \\
\hline & Average & 1.65 & 1.60 & 1.61 \\
\hline
\end{tabular}

Exhibit TN-5. Student responses to case assessment questionnaire.

Student responses to the question "What suggestions for improvement to the case do you have?" included:

- "None, it was great!"

- "No improvements needed. This is one of the better cases I have worked on."

- "The case is well prepared. Nothing should be changed. Every question targets a different answer from a different area."

- "Communicate what you are expecting in terms of answers."

\section{Suggested solutions to the case discussion questions}

This section presents suggested answers to the ten questions assigned to this case.

Question 1 (LO 1): In the four-minute video, History of the FCPA (PBS, 2009) (http://youtu.be/ g1n0kat_i4s), former SEC Assistant Director Richard Grimes states that there are three parts of the FCPA that relate to both accounting and bribery provisions. The U.S. DOJ also provides "An Overview" (DOJ, 2013) of the FCPA provisions (www.justice.gov/criminal/fraud/fcpa). Requirements: (a) Describe 
briefly what the three FCPA parts referenced in the video are; and (b) describe briefly how Baker Hughes violated these accounting and bribery provisions in its Kazakhstan operations.

(a) Do not bribe foreign officials. The FCPA prohibits companies, employees, and agents from giving anything of value to foreign government officials in order to obtain or retain business.

Keep accurate books and records. Publicly listed companies have to maintain accurate books, records, and accounts which - in reasonable detail - accurately and fairly reflect the transactions of the company.

Establish and maintain strong internal controls. Publicly listed companies have to ensure that transactions are executed in accordance with management's authorization, that access to assets is permitted only in accordance with management's authorization, that financial statements are in accordance with U.S. GAAP, and that accounting records are compared with existing assets at reasonable intervals.The aforementioned rules are known as the anti-bribery and books and records provisions of the FCPA.

(b) Baker Hughes violated all three requirements. Baker Hughes and their intermediaries and agents paid bribes to foreign officials over an extended amount of time. Baker Hughes' top management discussed these bribes in detail and also asked their subcontractors to participate in paying for the bribe. Baker Hughes recorded the bribes as commissions, fees, and legal services, even though no legal or other identifiable service was performed for Baker Hughes. Internal control at Baker Hughes failed as there was no investigation into the dealings of Baker Hughes' agent in Kazakhstan, as well as no follow-up from Baker Hughes' legal department on concerns the legal department had raised in regards to FCPA compliance. Furthermore, Baker Hughes had a poor control environment, as the tone at the top failed to prevent the bribery. Multiple executives had knowledge of the bribes and failed to stop the payment of bribes. Baker Hughes violated U.S. GAAP as the significant payments were intentionally accounted for in incorrect accounts in an attempt to conceal the bribes.

Question 2 (LO 2, LO 3): In responding to the 2007 penalties, Baker Hughes has created a FCPA Compliance Guide (Baker Hughes, Inc., 2011) that facilitates employee understanding and compliance with the FCPA (www.bakerhughes.com/company/compliance/foreign-corrupt-practices-act). Refer to Section 2 of the guide on page 14 and describe Baker Hughes' "Financial Integrity" requirements.

In its financial integrity requirements, Baker Hughes establishes its commitment to the highest standards of accuracy and completeness in the documentation and reporting of financial accounting. All financial information must reflect actual transactions and conform to U.S. GAAP or local GAAP, as applicable. Employees are prohibited from making any false or misleading book entries and employees are directed to maintain a system of internal control that provides reasonable assurance that all transactions are executed according to management's authorization.

Question 3 (LO 1): Access the source document entitled A Resource Guide to the U.S. Foreign Corrupt Practices Act (U.S. DOJ \& SEC, 2012) provided on the SEC website (www.sec.gov/spotlight/fcpa/fcpa-resource-guide.pdf). What are the criminal and civil penalties for both individuals and corporations in violation of the anti-bribery and accounting provisions of the FCPA?

\section{(a) Criminal penalties}

For each violation of the anti-bribery provisions, the FCPA provides that corporations are subject to a fine of up to $\$ 2$ million. Individuals, including officers, directors, stockholders, and agents of companies, are subject to a fine of up to $\$ 100,000$ and imprisonment for up to five years.

For each violation of the accounting provisions, the FCPA provides that corporations and other business entities are subject to a fine of up to $\$ 25$ million. Individuals are subject to a fine of up to $\$ 5$ million and imprisonment for up to 20 years. 


\section{(b) Civil penalties}

For violations of the anti-bribery provisions, corporations are subject to a civil penalty of up to $\$ 16,000$ per violation. Individuals, including officers, directors, stockholders, and agents of the companies, are similarly subject to a civil penalty of up to $\$ 16,000$ per violation, which may not be paid by their employer or principal.

For violations of the accounting provisions, the SEC may obtain a civil penalty not to exceed the greater of (a) the gross amount of the pecuniary gain to the defendant as a result of the violations, or (b) a specified dollar limitation.

Question 4 (LO1, LO 2): The case mentioned local laws such as the Sarbanes-Oxley Act (SOX) of 2002 (U.S. Congress, 2002) and the UK Bribery Act of 2010 (Legislation.gov.uk, 2010), as well as international anti-bribery agreements that have been created by the OECD in 1997 (OECD, 1997). As a Baker Hughes audit committee member, what would you want Baker Hughes' employees to be aware of as regards SOX, the UK Bribery Act, and the OECD Convention?

Employees should be aware of additional laws that relate to bribery and business ethics. SoX introduced reforms to strengthen internal control, requires the company's principal officers to certify the integrity of their company's financial reports, mandates that public companies offer whistleblower hotlines, and requires management and the external auditor to report on the adequacy of the company's internal control on financial reporting. The UK Bribery Act of $\mathbf{2 0 1 0}$ covers individuals and companies that carry on business in the UK and does not include an exception for facilitating payments. Recipients of bribes can also be charged and bribes can be provided to a broader range of individuals rather than only foreign or government officials to make the act applicable. The OECD Convention was adopted by 40 countries (including the US) and establishes legally binding standards to criminalize bribery of foreign public officials in international business transactions. Each country has to undergo a peer review examination and the reports are made publicly available.

Question 5 (LO 2, LO 6): What are the components of an effective Corporate Ethics and Anti-Corruption Compliance Program that audit committee members should consider implementing when facing risks similar to the FCPA risks that Baker Hughes faced? Refer to the April 26, 2007 Baker Hughes press release (Norris, 2007), which is available on the Baker Hughes website under the tab entitled "Press Room" (www.bakerhughes.com/news-and-media/media-center/press-releases/4-26-2007-430-00-pm-baker-hughes-settles-previously-disclosed-fcpa-investigations).

If a company is subject to increased FCPA risks, management should consider the following measures to reduce the company's exposure to FCPA violations:

- Adopting enterprise-wide FCPA compliance policies.

- Establishing a strong whistleblower program that encourages early reporting of all potential FCPA violations and ensures no retaliation against whistleblowers.

- Providing computer-based and live FCPA compliance training to all employees.

- Taking swift disciplinary action including termination for non-compliance with the company's policies and procedures.

- Reducing the use of agents to obtain business.

- Certifying remaining agents for FCPA compliance.

- Conducting more internal audits in foreign countries.

Question 6 (LO 5): Various "Red Flags" can provide clues and tip a company off as to where FCPA risks may be lurking. During your audit committee review, you accessed the PowerPoint presentation, slides 21-25, by Jay Martin, Baker Hughes' Vice President and Chief Compliance Officer, that was given on June 5, 2008 (Martin, 2008) and reviewed the "red flags" listed there (www.docstoc.com/docs/ 2363177/Baker-Hughes-Incorporated-FCPA-Due-Diligence-Review-of-Non-U.S). In your opinion, which of the warning signs were likely present during the Kazakhstan FCPA violations? Describe the specific Baker Hughes case fact or action that relates to each red flag.

The red flags listed in Jay Martin's presentation that were present at Baker Hughes were: Rumors of improper payments; retention of unnecessary third parties (agent registered in the Isle of Man); convoluted payment requests ( $2 \%$ of the Kazakh oil services contract); unusually large commissions (more 
than $\$ 4$ million were paid from 2001 to 2003); doing business in a country with known corruption issues (Transparency International rated Kazakhstan as highly corrupt at the time of the Baker Hughes contract bidding); third-party non-US representative requesting up-front payments (agent registered in the Isle of Man with payments to a bank in London); third-party non-US representative having close relationships with government officials; and misrepresentation and inconsistencies in the application of the FCPA due diligence process of the third-party non-US representative (Roy Fearnley failed to abide by the Baker Hughes FCPA due diligence process).

Question 7 (LO 2, LO 4): The COSO report "Internal Control-Integrated Framework" (Committee of Sponsoring Organizations of the Treadway Commission (COSO), 2013) is the most commonly used and understood framework for evaluating internal controls over financial reporting. Since anti-bribery compliance programs are part of internal control, understanding the COSO framework is useful. Access the COSO Framework Executive Summary (www.coso.org/documents/990025P_Executive_Summary_final_may20_e.pdf). List and discuss each of the five components for effective internal control. Do you think that adherence to the COSO framework would have had the capacity to prevent Baker Hughes' FCPA violations? Why or why not?

The current COSO framework (Committee of Sponsoring Organizations of the Treadway Commission (COSO), 1992) will be in effect until December 15, 2014, with early adoption of the new COSO framework encouraged. The changes in the COSO framework do not affect the five components for effective internal control. According to the CoSo framework, the five components of effective internal control are: (1) The control environment, (2) risk assessment, (3) control activities, (4) information and communication and (5) monitoring activities. The control environment is the foundation for all other components of internal control and is often referred to as the "tone at the top," which is set by senior management and the board of directors. Risk assessment refers to the organization's identification and analysis of risks that have the capacity to adversely affect the organization's objectives. Control activities include policies and procedures that help ensure that necessary actions are taken to address potential risks. Information and communication describes the nature and quality of information needed for effective internal control and monitoring activities include ongoing and separate evaluations of the components of internal control.

Following the COSO framework would have had the capacity to prevent FCPA violations at Baker Hughes. A more ethical tone at the top, the follow-up of internal control on identified risks, and more control and monitoring activities would have exposed the proposed bribes and characterized them as unacceptable. Strong internal controls reduce the opportunities for management override, something that occurred at Baker Hughes.

Students can further utilize the seventeen principles listed in the new COSO framework to better explain the five components and how they relate to Baker Hughes' internal control deficiencies and FCPA violations.

Question 8 (LO 3): As a Baker Hughes audit committee member, you want to determine that the company performed the proper accounting and disclosure of the Kazakhstan violations and settlement. Access the Baker Hughes 10-Ks for the years 2005, 2006, 2007, and 2008 (Baker Hughes, Inc., 2005, Baker Hughes, Inc., 2006, Baker Hughes Inc., 2007c; Baker Hughes Inc., 2008) from the SEC website (www.sec.gov/edgar/searchedgar/companysearch.html) and do the following: (a) for each year, conduct a search (using the Control + F keys) for the word "FCPA." How did Baker Hughes account and disclose its Kazakhstan risk exposure during each of the four years? In your opinion, was their accounting treatment correct? (b) Using the most recent 10-Ks available, how did Baker Hughes' revenue develop in the years subsequent to 2007 ? Were Baker Hughes' revenues negatively impacted by the cessation of bribery activities under the FCPA?

Baker Hughes' disclosures regarding their FCPA violations increased over time. Prior to the settlement made in 2007, in the 10-K of 2005, footnote disclosure (Note 16. Commitments and Contingencies) was properly made of the litigation contingency related to the Baker Hughes situation in Kazakhstan. This was the proper treatment under U.S. GAAP for contingent liability accounting. A similar footnote disclosure was made in 2006 (Note 15). In 2007, the footnote contingent liability disclosure (Note 15) also included the details of the settlement agreement with the SEC. The 2008 financial statements included a full and accurate description of the settlement as follows: 
Under the settlements in connection with the previously disclosed compliance investigations by the DOJ and SEC, we are subject to ongoing review and regulation of our business operations, including the review of our operations and compliance program by an independent monitor appointed to assess our Foreign Corrupt Practices Act ('FCPA') policies and procedures. The activities of the independent monitor will have a cost to us and may cause a change in our processes and operations, the outcome of which we are unable to predict. In addition, the settlements may impact our operations or result in legal actions against us in the countries that are the subject of the settlements. Also, the collateral impact of settlement in the United States and other countries outside the United States where we do business that may claim jurisdiction over any of the matters related to the DOJ and SEC settlements could be material. These settlements could also result in third-party claims against us, which may include claims for special, indirect, derivative or consequential damages... Under the settlements with the DOJ and SEC, we are subject to a two-year deferred prosecution agreement and enjoined by the federal district court against any further violations of the FCPA. Accordingly, the settlements reached with the DOJ and SEC could be substantially nullified and we could be subject to severe sanctions and civil and criminal prosecution as well as fines and penalties in the event of a subsequent violation by us or any of our employees or our failure to meet all of the conditions contained in the settlements. The impact of the settlements on our ongoing operations could include limits on revenue growth and increases in operating costs. Our ability to comply with the terms of the settlements is dependent on the success of our ongoing compliance program, including our ability to continue to manage our agents and business partners and supervise, train and retain competent employees and the efforts of our employees to comply with applicable law and the Baker Hughes Business Code of Conduct.

Baker Hughes' revenue in USD million during the years 2007-2012 was as follows:

\begin{tabular}{llllll}
\hline 2007 & 2008 & 2009 & 2010 & 2011 & 2012 \\
$\$ 10,428$ & $\$ 11,864$ & $\$ 9,664$ & $\$ 14,414$ & $\$ 19,831$ & $\$ 21,361$ \\
\hline
\end{tabular}

Based on these numbers, the often-made argument that bribes are necessary or else the business collapses and employees have to be terminated does not hold true. Baker Hughes was able to focus on other areas and was able to be very successful while in compliance with the FCPA.

The financial statements disclose the payment of penalties but do not allow for the detection of the amount of bribes paid to the agent and the expenses Baker Hughes incurred due to its internal investigation. This is due to the highly aggregate nature of the presentation, as well as the high revenue of Baker Hughes.

Question 9 (LO 4): To what extent do external auditors have a responsibility to detect violations of the FCPA? What specific actions must external auditors take to discover fraud and illegal acts? Refer to AU 317 Illegal Acts by Clients (PCAOB, AU 317) and AU 316 Consideration of Fraud in a Financial Statement Audit (PCAOB, AU 316).

External auditors have a responsibility to detect material misstatements in financial statements, whether arising from error or fraud. All members of the audit team have to meet for a brainstorming session during which financial statement areas that might be susceptible to fraud are identified. The session should also include a discussion of how management could perpetrate and conceal fraudulent financial reporting and how assets of the entity could be misappropriated. The brainstorming session can also influence the audit program and the level of professional skepticism, which demands a questioning mind and critical assessment of audit evidence. In addition, auditors have to obtain information in order to identify risks of material misstatements due to fraud, e.g., through management inquiry, analytical procedures, and inquiry of the company's legal counsel. Auditors are also required to consider the possibility of fraud throughout the audit.

The following issues limit the auditor's ability to detect illegal acts: many illegal acts are not closely tied to financial statements and as such are difficult to detect for the external auditor; auditors lack the education of attorneys, which makes it difficult for auditors to determine whether an action is in fact a violation of the law; and auditors do not conduct a full investigation of all transactions, but rather provide reasonable assurance that is based on testing parts of the overall population. 
Because of these limitations, external auditors do not have explicit responsibilities in uncovering FCPA violations, but have to follow up on any red flags or indications for FCPA violations they become aware of during the audit. Students can also refer to the more recent PCAOB AS 12 (Identifying and Assessing Risks of Material Misstatements) and PCAOB AS 13 (The Auditor's Responses to the Risks of Material Misstatements). Alternatively, a professor teaching an auditing class could ask additional questions relating to these standards.

Question 10 (LO 2, LO 4, LO 6): In your opinion, what action should (a) an audit committee member, (b) an external auditor and (c) an employee take if he/she detects a possible violation of the FCPA?

A review of the AICPA or IMA ethical guidelines for CPAs and CMAs is helpful in answering this question. In general, internal issues that the company faces should not be communicated to anyone outside of the organization including authorities and attempts should first be made to resolve the issue internally.

(a) An audit committee member is in a meaningful position to combat FCPA violations and can request an investigation into the possible FCPA violation. The audit committee oversees the internal and external audit function and is responsible to ensure that the company's financial reporting is transparent, consistent, and accurate. The audit committee member should bring the issue to the attention of the full board as well as management and then follow up on subsequent results and determinations. The audit committee member should ensure that his or her concerns are accurately reflected in the minutes.

(b) External auditors have a responsibility to follow up on suspicions of possible violations of the law. At the very least, they have to address the issue to either management or the audit committee, depending on the severeness of the violation. Suspected FCPA violations would however call for an involvement of the audit committee. If the violation results in the financial statements not representing fairly the true economic position of the company, the auditor needs to assess the implications of the violation on the auditor's report. The auditor also needs to evaluate his or her relationship to management in light of a possible management misrepresentation and its implication on the auditor's ability to continue the audit.

(c) An employee should first review all relevant company policies and should follow these policies. The employee should then contact his or her immediate supervisor, assuming the supervisor is not involved in the violation. If no satisfactory solution is accomplished, the employee should submit the issue to the next management level and inform his or her immediate supervisor of this step, again assuming the supervisor is not involved. Employees that prefer to stay anonymous can contact the company ethics hotline. Employees can furthermore retain their own counsel and can choose to resign from their position.

\section{Conclusion}

The major contribution of this case lies in students learning about the importance of business ethics, strong corporate governance, and internal control - and the possible consequences if such are missing. The learning of specific FCPA rules is an added and important benefit as FCPA violations and corresponding enforcement actions have increased substantially in recent years. Overall, the assessment results indicate that the case achieves important learning objectives and that students find it relevant and valuable.

\section{Acknowledgements}

We wish to thank editor-in-chief, David E. Stout, and the anonymous associate editor and reviewers of the journal for their helpful comments. We are also grateful for the valuable feedback we received from participants of the 2012 AAA Ohio, Northeast, and Midwest Region Meetings as well as the 2013 AAA Annual Meeting. 


\section{References}

American Bar Association (2007), The securities enforcement manual: Tactics and strategies. Chicago, Illinois: American Bar Association.

Baker Hughes Inc. (2005). Form 10-K, Report, 12/31/2005. <www.sec.gov/Archives/edgar/data/808362/000095012906002136/ h33213e10vk.htm>.

Baker Hughes Inc. (2006). Form 10-K, Report, 12/31/2006. <www.sec.gov/Archives/edgar/data/808362/000095013407003991/ h43740e10vk.htm>.

Baker Hughes lnc. (2007a). Baker Hughes settles previously disclosed FCPA investigations [Press Release]. <www.bakerhughes.com/ news-and-media/media-center/press-releases/4-26-2007-4-30-00-pm-bakel-lutghes-settles-previously-disclosed-fcpainvestigations $>15.07 .13$.

Baker Hughes Inc. (2007b). Form 10-Q Report, 3/31/2007. <www.secinfo,com/dsvrp.u9bw.3.htm> 15.07.13.

Baker Hughes Inc. (2007c). Form 10-K, Report, 12/31/2007. <wwW.sec.gov/Archives/edgar/data/808362/000095012908001084/ h53535e10vk.litm>.

Baker Hughes Inc. (2008). Form 10-K, Report, 12/31/2008. <www.Sec.gov/Archives/edgar/data/808362/000095012908001084/ h53535e 10vk,htm>.

Baker Hughes Inc. (2010). Business code of conduct - Ethics and compliance guide. <www.bakerhughes.com/company/ compliance/business-code-of-conduct> 15,07.13.

Baker Hughes Inc. (2011). Foreign Corrupt Practices Act (FCPA) compliance guide. <www.bakerhughes.com/conpany/compliance/ foreign-corrupt-practices-act> 15.07.13.

Baker Hughes Inc. (2013). Corporate profile. <www.bakerhughes.com/company/about/about-baker-hughes-corporate-profile> 15.07.13.

Biegelman, M. T., \& Biegelman, D. R. (2010). Foreign Cornpt Practices Act compliance guidebook: Protecting your organization from bribery and corruption. Hoboken, New Jersey: John Wiley \& Sons.

Committee of Sponsoring Organizations of the Treadway Commission (COSO) (1992). Internal control - Integrated framework (Executive Summary). <www.coso.org/IC.htm> 24.01.14.

Committee of Sponsoring Organizations of the Treadway Commission (COSO) (2013). Internal control - Integrated framework (Executive Summary). <www.coso.org/IChtni> 15.07.13.

Crude Accountability (2013). Karachaganak. <itttp://crudeaccountability.org/canjpaigns/karachaganak> 15.07.13.

Deloitte (2013). Audit Committee Brief: Navigating anti-corruption compliance. <www.corpgov.deloitte.com/binary/ com.epicentric.contentmanagement.servlet.ContentDeliveryServlet/USEng/Documents/Deloitte\%20periodicals/ Audit\%20Comnittee\%20Brief/ACBrief_October2013.pdf>02.11.13.

GlobalEdge, Michigan State University (2013). Kazakhstan: Economy, <https:/globaledge.msu.edu/countries/kazakhstan/ ecolnomy> 15.07.13.

Hasen, R. L. (2012). Remedies: Examples and explanations (3rd ed.). New York, New York: Aspen Publishers.

Karachaganak Petroleum Operating B.V. (2002). Executive summary - Environmental and social status of the Karachaganak Oil and Gas Condensate Field. <http://ifcext.ifc.org/ifcext/spiwebsitel.risf/bdab850a866532ee8525797d00698c58/ Gef3ba3egG15e319852576c10080ch40/\$FILE/ESFinal.pdi 24.01.14.

Kazakhstan.com (2013). Kazakhstan, Republic of Kazakhstan. <www.kazakhstan.com/v/city_info> 05.07.13.

KPMG Audit Committee Institute (2012). Audit Committee Priorities for 2013. KPMG LLP. <www.kpmginstitutes.com/aci/insights/ $2012 / \mathrm{kpmgs}$-audit-conmittee-priorities-for-2013.aspx> 18.07.13.

Legislation.gov.uk (2010). UK Bribery Act of 2010. <www.legislation.gov.uk/ukpga/20 10/23/contents> 18.07.13.

Leigh, D. (2010). Wikileaks cables name UK banker as middleman in Kazakh corruption ring. The Guardian (Dec 12, 2010). <www.guardian.co.uk/world/2010/dec/12/wikileaks-british-banker-kazakh-corruption> 15.07.13.

Loughman, B. P., \& Sibery, R. A. (2012). Bribery and comption: Navigating the global risks. Hoboken, New Jersey: Jolun Wiley \& Sons.

Martin, J. G. (2008). Baker Hughes Incorporated FCPA due diligence review of non-U.S. <www.docstoc.com/docs/2363177/BakerHughes-Incorporated-FCPA-Due-Diligence-Review-of-Non-US> 15.07.13.

Miller Chevalier (2011). FCPA winter review 2011 - International alert. <www.millerchevaliercom/Publications/ MillerChevalierPublications?find $=48909>$.

Norris, F. (2007). Baker Hughes admits to overseas bribery. New York Times. <www.nytimes.com/2007/04/27/business/ worldbusiness/27settle.html? $r=0>15.07 .13$.

OECD (1997). OECD convention on combating bribery of foreign public officials in international business transactions. <www.oecd.org/corruption/oecdantibriberyconvention.litm> 15.07.13.

PBS (2009). Spotlight: History of the FCPA. <www.pbs.org/frontlineworld/stories/bribe/2009/02/history of-the-fcpa,html> 15.07.13.

PCAOB AU 316 - Considerations of fraud in a financial statement audit. <http://pcaobus.org/Standards/Auditing/Pages/ AU316.aspX> 28.09.13.

PCAOB AU 317 - Hlegal acts by clients. <http://pcaobus.org/5tandards/Auditing/Pages/AU317.aspx> 28.09.13.

SEC (2007a). Litigation Release No. 20094 and Accounting and Auditing Enforcement Release No. 2602. <www.sec.gov/litigation/ litreleases/2007/120094.htm> 15.07.13.

SEC (2007b). SEC charges Baker Hughes with foreign bribery and with violating 2001 commission cease and Desist order. <www.sec.gov/news/press/2007/2007-77.htm> 15.07.13.

SEC v. Baker Hughes (BH) (2007). No. 07-cv-1408 (United States District Court, Southem District of Texas, Houston Division 2007). <www.sec,gov/litigation/litreleases/2007/1r20094.htm> 15.07 .13 .

Transparency International (2012). Transparency in corporate reporting: Assessing the world's largest companies. <wwW.transparency.org/whatwedo/pub/transparency_in_corporate_reporting_assessing_the_worlds_largest_companies> 15.07.13.

Transparency International (2014), Corruption by Country - Kazakhstan. <www.transparency,org/country\#KAZ> 18.01.14.

U.S. Congress (2002). Sarbanes-Oxley Act of 2002. <www.govtrack.us/congress/bill/107/hr3763> 15.07.13. 
U.S. Department of State, Bureau for International Narcotics and Law Enforcement Affairs (2001). Fighting global corruption: Business risk management. <www.state,gov/g/inl/rls/rpt/fgcrpt/2001>15.07.13.

U.S. Department of Justice (DOJ) (2013). Foreign Corrupt Practices Act - An overview. <www.justice.gov/criminal/fraud/fcpa> 15.07.13.

U.S. Department of Justice (DOJ) and U.S. Securities and Exchange Commission (SEC) (2012). A resource guide to the U.S. Foreign Corrupt Practices Act. <www.justice.gov/criminal/traud/fcpa/guidance> 15.07.13.

Urofsky, P., \& Newcomb, D. (2013). FCPA digest: Cases and review releases relating to bribes to foreign officials under the Foreign Compt Practices Act of 1977. <www.shearman.com/Shearman-Sterlings-Recent-Tiends-and-Patterns-in-the-Enforcementof-the-Foreign-Cornipt-Practices-Act-FCPA-FCPA-Digest-2013-01-02-2013>.

World Bank (2004). The cost of corruption. <http://Web.worldbank.org/WBSTTE/EXTERNAL/NEWS/0, contentMDK: 20190187 menuPK:34457 pagePK:34370 piPK:34424 -theSitePK:4607,00.html> 15.07.13. 